license

\title{
Pemekaran Daerah Luwu Raya Sebagai Isu Kampanye Pemilihan Gubernur Sulawesi Selatan
}

\author{
Suhardiman Syamsu ${ }^{1}$, Reksa Burhan ${ }^{2}$, Ade Irma Surani Haliq ${ }^{3}$ \\ suhardimanfisip.unhas@gmail.com¹, reksaburhan@gmail.com², Dedhegunner@gmail.com³ \\ ${ }^{1}$ Departemen Ilmu Pemerintahan, Universitas Hasanuddin \\ ${ }^{2}$ Ladem Institut, Makassar \\ ${ }^{3}$ Universitas Muhammadiyah Palopo \\ DOI: http://dx.doi.org/10.22219/sospol.v6i2.12898
}

\begin{abstract}
Regional expansion is argued to improve people's welfare, the quality of public services, create good and efficient local government, and build substantive democracy at the local level. Regional expansion must consider aspects of urgency and capacity. The policy process for regional expansion in Indonesia is bottom-up and is dominated by a political process rather than an administrative process. This issue raised in the momentum of the Pilkada, but until the 2018 period it had not yet been realized. This study aims to explain the issue of regional expansion of Luwu Raya during the regional elections for Governor and the Vice Governor of South Sulawesi in 2009, 2013 and 2018 and the obstacles. Data obtained from official government documents and reports. The data presented is the result of the clustering process, descriptive analysis of interview transcripts and processed as research results. The relationship between the elite is the focus of the analysis in this study. Researchers further explore the political dynamics of local elites in the discourse of regional expansion. It examines the issue of regional expansion becomes a political campaign maneuver aims to collect electoral votes. The concept of decentralization does not made the political process of regional expansion easily to realize. The practice of decentralization governance not only changing the implementation of governance in the regional administrative but also the implementation of politics at the local level. Political elites compete for electoral barns as a manifestation of local political practices that coincide with the issue of regional expansion.
\end{abstract}

\section{Abstrak}

Pemekaran daerah diyakini dapat meningkatkan kesejahteraan rakyat dan kualitas pelayanan publik, menciptakan pemerintah lokal yang baik dan efisien, serta membangun demokrasi subtantif di tingkat lokal. Pemekaran daerah harus mempertimbangkan aspek urgensi dan kapasitas. Proses kebijakan pemekaran daerah di Indonesia bersifat bottom-up dan lebih didominasi oleh proses politik dibandingkan proses administratif. Wacana pemekaran selalu dimunculkan pada momentum Pilkada namun hingga periode tahun 2018 belum juga terealisasi. Penelitian ini bertujuan menjelaskan wacana pemekaran Luwu Raya pada proses Pilkada Cagub dan Cawagub tahun 2009, 2013, dan 2018 serta faktor yang mempengaruhi kegagalannya. Sumber data diperoleh dari dokumen dan laporan resmi pemerintah, antara lain laporan berkala BPS dan laporan resmi yang telah dirilis oleh beberapa instansi. Data yang disajikan merupakan hasil dari proses klasterisasi, analisis desktiptif transkrip wawancara dan diolah sebagai hasil penelitian. Relasi antara elit menjadi fokus yang dianalisis pada penelitian ini. Peneliti mengeksplorasi lebih jauh dinamika politik elit lokal dalam wacana pemekaran daerah. Hasil penelitian menjelaskan wacana pemekaran daerah menjadi maneuver politik kampanye yang bertujuan menarik keberpihakan suara elektoral. Perubahan konsep tata kelola pemerintahan menjadi otonomi daerah tidak menjadikan upaya pemekaran daerah menjadi mudah. Hal ini disebabkan desentralisasi tidak hanya mengubah pelaksanaan pemerintahan di daerah tetapi pada aspek tertentu membuat reformasi politik yang imbasnya bagi pelaksanaan politik di tingkat lokal. Para elit politik berkompetisi memperebutkan lumbung elektoral sebagai salah wujud praktek politik lokal yang bergelindan bersamaan dengan isu pemekaran daerah.

\author{
Keywords \\ Campaign, \\ Decentralization, \\ Elections, Local \\ Government, \\ Regional \\ Expansion
}

\section{Article History}

Received July 14, 2020

Revised

September 4, 2020

Accepted

September 22,

2020

Published

November 20, 2020

\section{Corresponding}

\section{Author}

Suhardiman

Syamsu.

Departemen

Ilmu

Pemerintahan/Fi

sip Unhas, Jln.

Perintis KM 10,

Makassar. 
license

\section{Pendahuluan}

Sejak beberapa dekade terakhir, pemekaran daerah menjadi wacana dominan yang mewarnai perdebatan para sarjana. Sebagian besar berpendapat pemekaran daerah sebagai indikasi menguatnya praktik desentralisasi. Pandangan ini meyakini pemekaran daerah 'membawa wajah baru' bagi pelaksanaan pemerintahan/otonomi daerah. Desentralisasi memperkuat aspek lokalitas, mendorong ruang partisipasi, mengedepankan transparansi, sebuah rangkaian kebijakan yang membuat pelaksanaan penyelenggaraan pemerintahan menjadi lebih akuntabel. Namun, tidak sedikit yang melihat praktek desentralisasi sebagai masa kemunduran penyelenggaraan pemerintahan di Indonesia. Tanggapan ini terutama datang dari pihak yang percaya bahwa otonomi dan desentralisasi daerah tidak banyak mengubah struktur politik di Indonesia (Nur, Wekke, \& et.al, 2017; Suaib \& Zuada, 2015). Sebaliknya, desentralisasi dan otonomi daerah justru membuat praktik penyelenggaraan pemerintahan di daerah menjadi lebih rumit. Desentralisasi dan otonomi daerah menciptakan kekuatan politik lokal yang baru, membuat relasi daerah menjadi lebih kompleks dan pada konteks tertentu melahirkan sejumlah praktik tata kelola pemerintahan yang kurang efisien (Beier \& Ferrazzi, 1998; Carnegie, 2008; Ferrazzi, 2000; Hadiz, 2004; Ito, 2006).

Pemekaran daerah merupakan salah satu sarana desentralisasi untuk meningkatkan kesejahteraan rakyat dan kualitas pelayanan publik, menciptakan pemerintah lokal yang baik dan efisien, serta membangun demokrasi subtantif di tingkat lokal. Suatu daerah dapat dimekarkan dengan dua macam pendekatan, yaitu potensi dan urgensi (Ratnawati, 2007). Dalam pendekatan potensi, suatu daerah yang berpotensi untuk dimekarkan minimal harus memenuhi persyaratan ekonomi, kapasitas pemerintah dan tolak ukur politik. Secara ekonomi, daerah harus memiliki sumber-sumber ekonomi pendukung, ditunjang oleh jumlah penduduk yang cukup serta lokasi daerah pemekaran harus telah beroperasi sejumlah perusahaan/ kegiatan ekonomi investasi (PMA/PMDN) dan terakhir ketersediaan fasilitas publik seperti jalan-jalan beraspal hingga pelosok daerah, transportasi, listrik, air bersih, sekolah-sekolah dari TK hingga perguruan tinggi/ minimal Akademi, rumah sakit umum daerah, Bank (Pemerintah/Swasta), media massa lokal. Sementara itu, dalam aspek kapasitas pemerintah, daerah pemekaran setidaknya memiliki potensi manajemen pemerintahan yang baik yang diukur dari, pegawai yang kompeten dan memadai dalam kuantitas dan kualitas, dan pengelolaan keuangan dan anggaran yang transparan dan akuntabel. Terakhir aspek yang paling penting adalah aspek politik. Daerah pemekaran harus memperhatikan aspek stabilitas keamanan daerah yang cukup baik, tidak ada/ minim potensi konflik SARA (Burhan, 2020).

Sementara itu, pendekatan urgensi meyakini pemekaran daerah dapat dilakukan untuk daerah-daerah perbatasan yang umumnya "kurang mampu" (khususnya ekonomi dan kualitas SDM) namun urgen atau penting dimekarkan demi pertimbangan pertahanan/ keamanan nasional atau kepentingan nasional lainnya. Daerah-daerah kategori sebelum berotonomi penuh ini harus melalui otonomi persiapan. Dalam pembentukan suatu daerah atau wilayah pemekaran diperlukan adanya suatu ukuran sebagai dasar penetapan (Agustino \& Yusoff, 2010). Pembentukan dan pemekaran wilayah yang baru harus didasarkan atas pembagian-pembagian yang bersifat objektif dengan memperhatikan segi pembiayaan sumber daya manusia serta sarana penunjang lainnya. 


\section{Pemekaran Daerah di Indonesia}

Pembentukan daerah otonom baru (DOB) melalui proses pemekaran daerah otonom sudah dikenal sejak masa pemerintahan Sukarno. Memasuki pemerintahan Suharto, pemekaran daerah terjadi dalam jumlah yang sangat terbatas. Baik pada masa pemerintahan Sukarno maupun Suharto, mayoritas pembentukan daerah otonom meewujud dalam bentuk pendirian Kotamadya sebagai konsekuensi proses peng-kota-an sebagian wilayah sebuah Kabupaten. Prosesnya pun diawali dengan pembentukan kota administratif sebagai wilayah administratif, yang kemudian baru bisa dibentuk menjadi Kotamadya sebagai daerah otonom. Selama kurun waktu 1945 hingga awal era Reformasi, proses pemekaran daerah lebih bersifat top-down atau sentralistik yang tampak melalui proses teknokratis-administratif. Hal ini semakin diperkuat oleh UU No. 22 Tahun 1999 yang menonjolkan kuatnya kewenangan pemerintah pusat dalam upaya pemekaran daerah.

Seiring waktu, UU No. 22 Tahun 1999 direvisi menjadi UU No. 32 Tahun 2004 tentang Pemerintahan Daerah. Revisi UU tersebut didasari oleh implementasi dari semangat reformasi yang menghendaki pelaksanaan pemerintahan yang lebih demokratis. Salah satunya ialah melalui perwujudan tata kelola pemerintahan yang lebih otonom. Dalam UU No. 32 Tahun 2004, daerah diberi ruang lebih besar untuk mengembangkan wilayah sesuai dengan karakteristik dan sumberdaya yang dimiliki. Pada perkembangannya, UU tersebut disempurnakan menjadi UU No. 23 Tahun 2014. Dalam perubahan kedua ini, poin utama yang direvisi adalah soal pembagian kekuasaan di tingkat lokal, terutama penguatan peran eksekutif dan legislatif serta demokratisasi melalui pemilu di tingkat daerah. Konteks inilah yang kemudian menjadi pintu masuk isu pemekaran menjadi isu kampanye.

Sejak 2001, proses kebijakan pemekaran daerah bersifat bottom-up dan lebih didominasi oleh proses politik daripada proses administratif. Wujud dari pelaksanaan kebijakan bottom-up tercermin dari isu pemekaran yang mengabaikan aspek-aspek administratif, seperti luas wilayah ketersediaan sumberdaya dan potensi daerah. Secara bersamaan isu pemekaran lebih di dominasi oleh dorongan dan motif politik tertentu. Prosesnya pun sangat bervariasi. Diawali oleh dukungan aspirasi masyarakat, diusulkan oleh kepala daerah dan DPRD induk, lalu dimintakan persetujuan dari kepala daerah dan DPRD daerah atasan, kemudian diusulkan ke pemerintah Nasional yang melibatkan Menteri Dalam Negeri, Dewan Pertimbangan Otonomi Daerah (DPOD) dan DPR/DPD RI. kebijakan ini dimulai pada saat legitimasi pemerintah yang lemah menghadapi tekanan politik masyarakat dan politisi daerah (Bappenas, 2008).

Dalam konteks administratif, pembentukan daerah otonom baru bertujuan untuk menciptakan efisiensi dan efektivitas dalam penyelenggaraan pemerintahan daerah dan pelayanan publik. Rentang kendali pemerintahan yang terlalu luas dan jangkauan layanan yang terlalu jauh, jelas-jelas akan membawa konsekuensi pada semakin lemahnya fungsi kontrol dan sekaligus mengakibatkan pada rendahnya kualitas pelayanan publik. Dalam perspektif ini pembentukan daerah baru melalui proses pemekaran merupakan instrumen yang tepat untuk menutup kelemahan problematika rentang kendali dan jangkauan pelayanan Namun, tidak sedikit yang juga telah berhasil menata pemerintahan daerah melalui semangat desentralisasi (Miller \& Bunnell, 2013; Sutiyo, Maharjan, \& Keshav Lall, 2017; Talitha, Firman, \& Hudalah, 2019; Warren \& Visser, 2016). 
Berdasarkan kedua dimensi tersebut, maka manajemen transisi dalam penyelenggaraan pemerintahan daerah otonom mencakup dua hal yaitu; Penataan Politik dan Administrasi Pemerintahan. Dalam penataan admisitrasi pemerintahan daerah, tercakup pula penataan kelembagaan pemerintahannya. Namun hal yang perlu diperhatikan adalah bahwa, pemekaran daerah yang terjadi setelah diterapkannya UU No.22 Tahun 1999, tidak didorong oleh latar belakang yang seragam, dan tidak pula membawa dampak yang sama. Oleh karena itu problematika pemekaran di masing-masing daerah mempunyai ke-khas-annya sendiri yang tidak mudah untuk di genaralisasikan. Sebagai konsekuensinya dalam hal manajemen transisinya, di masing-masing daerah otonom baru tidak sama antara daerah yang satu dengan daerah lainnya, tergantung pada latar belakang terbentuknya daerah otonom, kesiapan daerah otonom baru, dan kompleksitas permasalahan dalam proses pembentukan daerah otonom baru tersebut. Dalam hal ini pemahaman terhadap kondisi politik dan pemerintahan sebelum terbentuknya daerah otonom baru menjadi sangat penting.

Tulisan ini berupaya menjelaskan wacana pemekaran Luwu Raya pada setiap proses Pilkada Cagub dan Cawagub yang berlangsung di Sulawesi Selatan pada periode tahun 2009, 2013, dan 2018. Studi kasus di Luwu Raya menarik untuk diamati sebagai salah satu isu pemekaran daerah di Indonesia. Wacana pemekaran telah digaungkan sejak masa awal kemerdekaan namun hingga periode Pilkada 2018 belum juga terealisasi. Pilkada di Luwu sejak 2007 menjadi panggung terbuka untuk mempertontonkan "isu pemekaran" yang berkelindan bersamaan dengan proses elektoral.

Tuntutan pemekaran daerah merupakan fenomena umum di Indonesia pasca gelombang desentralisasi (Smoke \& Lewis, 1996). Namun, wacana pemekaran di Luwu sesungguhnya telah bergulir sebelum gelombang desentralisasi terjadi. Oleh sebab itu, tarik-ulur kepentingan politik di Sulawesi Selatan terhadap pemekaran daerah Luwu Raya menarik untuk dianalisis. Mengingat janji kampanye Pilkada semua calon pemimpin daerah terhadap pemekaran bagi Tana Luwu selalu gagal direalisasikan, maka tulisan ini tertarik untuk menjelaskan faktor-faktor yang menyebabkan kegagalan tersebut.

\section{Metode}

Penelitian ini berlangsung di Luwu, Sulawesi Selatan dengan menggunakan pendekatan kualitatif. Teknik pengumpulan data dilakukan melalui obersevasi langsung dan wawancara. Metode ini memungkinkan peneliti untuk terlibat secara langsung sekaligus membangun interaksi yang lebih intens dengan informan di lokasi penelitian. Sejumlah tokoh dan elit lokal yang menjadi informan kunci pada penelitian ini diantaranya mantan anggota DPR-RI, Kelompok Pemuda di Luwu, Birokrat Tokoh Adat serta dua orang akademisi. Relasi antara elit menjadi fokus yang dianalisis pada penelitian ini. Peneliti mengeksplorasi lebih jauh dinamika politik elit lokal dalam wacana pemekaran daerah.

Sumber data yang diperoleh berasal dari dokumen dan laporan resmi pemerintah, antara lain laporan berkala BPS dan laporan resmi yang telah dirilis oleh beberapa instansi. Data yang disajikan merupakan hasil dari proses klasterisasi, analisis desktiptif transkrip wawancara dan diolah sebagai hasil penelitian. Pengumpulan data diselenggarakan selama tiga bulan melalui tiga kali periode. Periode pertama untuk tahap observasi berlangsung seminggu. Periode kedua adalah 
wawancara dan pengumpulan informasi lainnya. Selanjutnya, periode ketiga merupakan analisis deskriptif finalisasi penelitian dengan memperhatikan kaidah-kaidah penulisan ilmiah.

\section{Hasil dan Pembahasan}

\section{Proses Politik Wacana Pemekaran Luwu}

Luwu pertama kali menyuarakan wacana politik pemekaran daerah pada tahun 1999. Berdasarkan hasil wawancara, tuntutan ini berawal dari permintaan pemberian hak istimewa yang berkembang menjadi isu pemekaran daerah. Namun, tuntutan pemekaran daerah oleh para elit lokal berusaha ditenggelamkan oleh pemerintahan Orde Baru. Isu pemekaran daerah kembali mengemuka pasca berakhirnya pemerintahan Presiden Soeharto (Mutty, 2018). Kenyataan ini didukung oleh pemerhati adat di Luwu. Berdasarkan hasil wawancara, isu pemekaran muncul sebagai kesadaran akan sejarah Luwu yang merupakan kerajaan besar. Fakta sejarah inilah yang menguatkan para tokoh elemen adat mendukung realisasi pemekaran daerah (Akbar, 2018).

Penulis meyakini momentum Reformasi menempatkan wacana pemekaran daerah di Luwu menjadi dua perspektif. Menurut pandangan yang pertama, reformasi telah menghidupkan kembali imajinasi politik masyarakat Luwu tentang pemberian hak istimewa yang selanjutnya di terjemahkan menjadi isu pemekaran. Tetapi perspektif yang lain menyatakan bahwa para elit lokal tidak semua menginginkan terjadinya pemekaran daerah. Ada beberapa elit lokal yang tidak rela secara politik melepaskan Luwu menjadi daerah otonomi sebagai pihak-pihak yang diuntungkan secara ekonomi dan elektoral terhadap keberadaan Luwu menjadi bagian dari Sulawesi Selatan. Pihak-pihak tersebut disinyalir berasal dari oknum elit birokrasi di Luwu yang memiliki kaitan yang cukup besar dengan suara basis elektoral dan pembagian kewenangan serta alokasi anggaran yang digelontorkan dari pusat ke pemerintah Provinsi.

Dengan skema seperti ini, dapat dilihat bahwa isu pemekaran ditengah iklim refomasi menjadi arena konflik yang justru memperhadapkan antara elit lokal di Luwu dengan elit lokal di Provinsi Induk (Sulawesi Selatan). Konflik ini akan dijelaskan lebih jauh pada bagian berikutnya, dimana reformasi pada gilirannya justru membuat situasi menjadi tidak jauh lebih baik. Sebaliknya, dengan arena yang sangat terbuka memungkinkan dua entitas politik saling berbenturan antara mereka yang menginginkan pemekaran dengan mereka yang tidak menginginkan pemekaran. Situasi semakin kompleks dengan pertautan yang berlangsung baik oleh dinamika politik dikancah nasional dengan tautan politik yang berlangsung di skala lokal. Sehingga tidak sedikit yang kemudian mejadikan isu pemekaran sebagai jualan politik ketika berlangsung proses elektoral di daerah. Hal ini semakin menegaskan bahwa isu pemekaran tidak lebih sebagai komoditas politik di tengah besarnya ekspektasi masyarakat Luwu terhadap pemberian otonomi di wilayah mereka. Pemekaran memang jadi mimpi politik bagi masyarakat Luwu, hingga saat ini yang belum juga terwujud. Apalagi ditengah reformasi politik, angan mengenai hak otonomi dan pemekaran semakin menguat. Hal ini karena akses dan keterbukaan politik semakin terbuka lebar. Sehingga dengan situasi seperti itu, animo masyarakat untuk segera mungkin mendapatkan pemekaran dapat terwujud.

Tetapi faktanya, animo yang tentang tingginya minat pemekaran justru berbarengan dengan dinamika politik yang semakin terbuka. Salah satunya melalui proses elektoral. ditengah situasi yang tidak saling menguntungkan ini akhirnya membuat dinamika isu mengenai pemekaran justru menjadi isu empuk untuk dijadikan sebagai komoditas politik. Tidak heran jika 
setiap perhelatan politik elektoral yang berlangsung di skala lokal selalu menjadikan isu pemekaran sebagai isu untuk menggalang dukungan dari masyarakat Luwu. Khususnya pada setiap kontestasi Pilgub. Setelah reformasi, hampir setiap kontestasi Pilgub yang berlangsung di Sulsel menjadikan isu pemekaran sebagai salah satu isu untuk menarik simpati masyarakat Luwu. Bukan hanya itu, disetiap proses elektoral yang berlangsung kontestasi yang bertarung di Pilgub selalu menampilkan sosok putra daerah yang berasal dari Luwu, dan tidak sedikit figur yang mengatasnamakan dirinya sebagai Putra daerah tampil sebagai orang yang kemudian menjanjikan isu pemekaran. Tetapi tentu saja dengan prasyarat bahwa isu itu akan diwujudkan ketika terpilih dan berhasil memenangi kontestasi yang berlangsung. Meskipun di banyak kesempatan, selalu berujung dengan hal sebaliknya.

Sejak Pilkada 2007 dengan sangat jelas isu pemekaran selalu menjadi isu yang dikampanyekan oleh Syahrul Yasin Limpo gubernur saat itu selama melakukan kampanye di Luwu, dan selama 10 tahun juga isu tersebut tidak pernah terealisasi dengan baik. Bahkan di periode kedua SYL sama sekali isu pemekaran belum juga dapat direalisasi (Chaeruddin, 2019b; Lagaligopos, 2013; Zainuddin, 2018b). Pada pemilihan Gubernur yang berlangsung tahun 2018, dimana pada proses kontestasi yang berlangsung saat itu mempertemukan salah satu pasangan petahanan yaitu mantan wakil Gubernur dengan adik kandung SYL, dan berdasarkan informasi pada media massa kita dapat memahami bagaimana para kandidat yang berkompetisi pada ajang pemilihan Gubernur kembali menjadikan pemekaran daerah sebagai politik kampanye untuk menarik perhatian para pemilih (Koran Tempo, 2013; Mawardi, 2018; Sindonews, 2018; Yahmin, 2018; Zainuddin, 2018a).

\section{Luwu Sebagai Lumbung Elektoral di Sulsel}

Luwu sebagai daerah otonomi dengan jumlah pemilih mencapai 12,33\% wajib pilih dalam kancah politik lokal, selalu menjadi salah satu daerah yang secara elektoral punya pengaruh sangat besar. Selain karena situasi geopolitik yang seringkali memperhadapkan etnis dan kedaerah, salah satu yang membuat Tana Luwu sebagai arena seksi dalam politik lokal di Sulawesi Selatan adalah sumbangsih elektoral yang sangat besar. Luwu Raya sebutan yang selama ini digunakan untuk daerah-daerah yang berada di pusaran Tana Luwu, seperti Kabupaten Luwu Luwu Timur, Luwu Utara dan Kota Palopo. Jika dikalkulasi, suara elektoral yang dapat digarap dari Luwu Raya mencapai 746.633 wajib pilih ini yang membuat perhatian Luwu Raya selalu mendapat perlakuan istimewa dalam isu elektoral.

Dari pengamatan penulis, sejak pemilihan Gubernur di Sulawesi Selatan, daerah Luwu Raya selalu mendapat ruang. Hal ini nampak pada beberapa kandidat yang maju pada pilkada Gubernur. Sejak, 10 tahun silam, tercatat pada Tabel 1. putra Luwu selalu digandeng ke dalam pertarungan elektoral. Salah satu keluarga yang hingga hari ini selalu merepresantasikan putra Luwu adalah kehadiran Klan Kahar Muzakkar. Klan Kahar Muzakkar tidak hanya menunjukan satu indikasi menguatnya politik patronase, tetapi bagi penulis kehadiran Klan Muzakkar dalam pilkada di Sulawesi selatan lebih kepada strategi politik untuk mengait khususnya para pemilih yang berada di sekitar Luwu. Apalagi dengan narasi politik yang selama ini berkembang, setiap proses Pilkada di Sulawesi Selatan selalu membenturkan antara orang berketurunan Luwu dengan orang diluar Luwu, baik itu dari keturunan Bugis atau Makassar. 
Tabel 1 Perolehan Suara pada Pemilihan Gubernur Tahun 2007

\begin{tabular}{|c|c|c|c|c|}
\hline Daerah & $\begin{array}{c}\text { Amin Syam - } \\
\text { Mansyur ramli }\end{array}$ & $\begin{array}{c}\text { Aziz Kahar } \\
\text { Mudzakkar- } \\
\text { Mubyl } \\
\text { Handaling }\end{array}$ & $\begin{array}{c}\text { Syahrul Yasin } \\
\text { Limpo - Agus } \\
\text { Arifin } \\
\text { Nu'mang }\end{array}$ & Suara Sah \\
\hline Palopo & 17.871 & 27.388 & 19.878 & 65.137 \\
\hline Luwu & 44.971 & 86.106 & 24.870 & 155.947 \\
\hline Luwu Utara & 35.662 & 38.194 & 60.717 & 134.573 \\
\hline Luwu Timur & 49.037 & 23.900 & 28.346 & 101.283 \\
\hline Total Suara & $\mathbf{1 4 7 . 5 4 1}$ & $\mathbf{1 7 5 . 5 8 8}$ & $\mathbf{1 3 3 . 8 1 1}$ & $\mathbf{4 5 6 . 9 4 0}$ \\
\hline
\end{tabular}

Sumber: Diolah Penulis dari KPU Sulawesi Selatan (2018)

Tabel 2. Perolehan Suara pada Pemilihan Gubernur Tahun 2013

\begin{tabular}{|c|c|c|c|c|}
\hline Daerah & $\begin{array}{c}\text { Ilham Arif } \\
\text { Sirajuddin - } \\
\text { Aziz Kahar } \\
\text { Mudzakkar }\end{array}$ & $\begin{array}{c}\text { Syahrul Yasin } \\
\text { Limpo- } \\
\text { Agus Arifin } \\
\text { Nu'mang }\end{array}$ & $\begin{array}{c}\text { A.Rudiyanto } \\
\text { Asapa- } \\
\text { A.Nawir } \\
\text { Pasinringi }\end{array}$ & $\begin{array}{c}\text { Suarah } \\
\text { Sah }\end{array}$ \\
\hline Palopo & 53.082 & 25.982 & 2.981 & 82.045 \\
\hline Luwu & 120.610 & 59.881 & 3.505 & 183.996 \\
\hline Luwu Utara & 74.728 & 70.074 & 4.360 & 149.162 \\
\hline Luwu Timur & 49.002 & 75.781 & 1.587 & 126.370 \\
\hline Total Suara & $\mathbf{2 9 7 . 4 2 2}$ & $\mathbf{2 3 1 . 7 1 8}$ & $\mathbf{1 2 . 4 3 3}$ & $\mathbf{5 4 1 . 5 7 3}$ \\
\hline
\end{tabular}

Sumber: Diolah Penulis dari KPU Sulawesi Selatan (2018)

Berdasarkan Gambar 2. secara geopolitik, Tana Luwu berada di garis utara Sulsel dengan basis pemilih yang cukup menjanjikan. Keberadaan daerah di Kawasan Luwu Raya dalam proses elektoral yang berlangsung di Sulawesi selatan, juga nampak pada isu-isu yang di narasikan oleh kandidat. Salah satunya, yang kontekstual dengan penelitian ini mengenai isu pemekaran Luwu. Hampir setiap menjelang deik-detik pilkada baik yang berlangsung untuk konteks lokal (Pemilihan Gubernur) maupun untuk konteks Pilpres, isu mengenai pemekaran masih saja selalu menjadi isu yang dijanjikan oleh elit-elit politik. Tidak sedikit elit politik dengan percaya dirinya, memberikan harapan akan pemekaran Provinsi Luwu Raya jika kelak terpilih agar masyarakat akar rumput di Tana Luwu berada pada satu sikap politik yang sama (Chaeruddin, 2019a, 2020; Mawardi, 2018; Pama'tan, 2018; Zainuddin, 2018b).

Narasi semacam ini bukan kali pertama hadir pada masyarakat Luwu. Sejak era pemerintahan Sahrul Yasin Limpo (SYL) isu mengenai pemekaran sudah menghiasi ruang-rang publik. Tercatat, salah satu janji kampanye pak SYL adalah memperjuangkan pemekaran Luwu menjadi provinsi baru. Kampanye ini sudah didengungkan SYL sejak periode pertama, ketika saat itu maju sebagai bakal Gubernur Sulawesi selatan bersama dengan Agus Arifin Nu'man. Nyatanya, diakhir masa jabatannya pemekaran Luwu belum direalisasikan, padahal saat itu SYL 
license

mendapat suara cukup besar di Luwu dengan perolehan suara mencapai 133.811 dari total suara 456.940. Tarik ulur kepentingan elit dan dukungan para elit menjadi salah satu pemicu rumitnya realisasi pemekaran di Luwu Raya (Burhan, 2020).

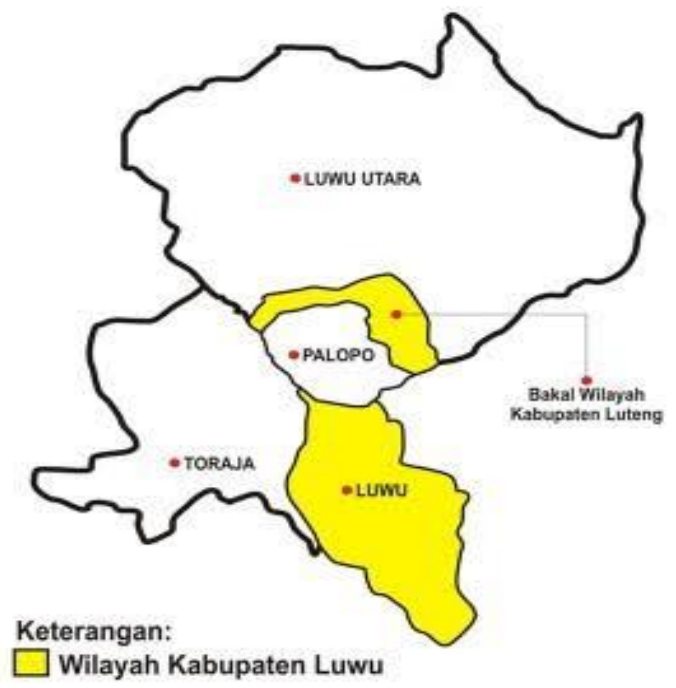

Gambar 2. Peta Rencana Pemekaran Wilayah Luwu Raya

Di periode berikutnya, Gambar 1. menunjukkan SYL maju kembali sebagai calon Gubernur bersama dengan pak Agus yang dikenal dengan Tagline kampanye "Sayang Jilid 2". Dalam perhelatan elektoral, kembali SYL mengangkat isu mengenai pemekaran. Kali ini bukan hanya SYL tetapi pada perhelatan ini, pasangan penantang mantan Wali Kota Makassar, Ilham Arief Sirajuddin menggandeng putra Luwu Abdul Aziz Kahar Mudzakkar. Masuknya Kahar sebagai wakil Ilham, menjadi indikasi akan perebutan elektoral yang kembali menyuguhkan perebutan elektoral.

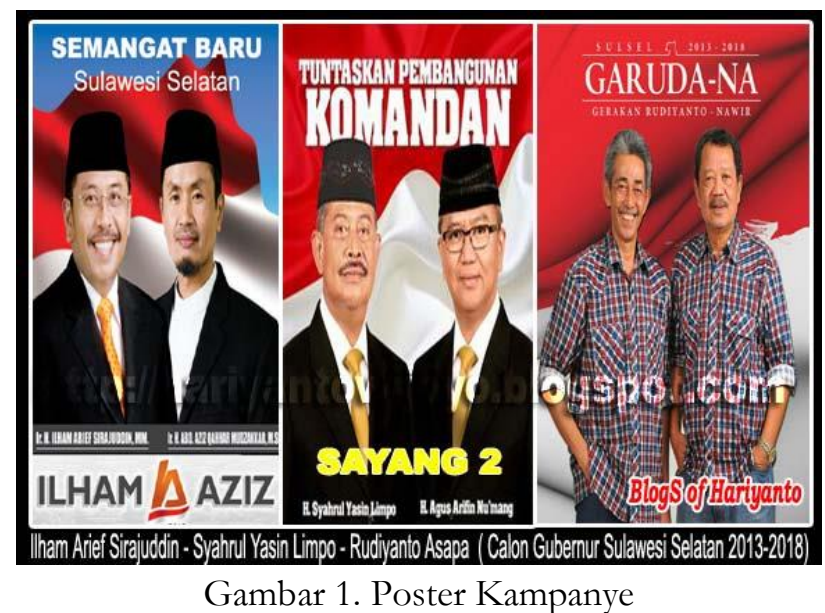

Dapat diamati pada Tabel 3, dengan strategi yang sama "Pemekaran Luwu Raya" pasangan Sayang Jilid 2 kembali merebut perhatian masyarakat Luwu. Lewat isu pemekaran Luwu, Sayang Jilid 2 berhasil mempertahankan tahta sebagai Gubernur. Meskipun, pasangan penantang telah mengagandeng putra daerah, tetapi saat itu masyarakat yang telah lama 
menginginkan pemekaran menjadi salah satu alasan yang membuat Sayang Jilid 2 mendapat kontribusi elektoral yang cukup efektif. Hingga akhir masa jabatannya, pemekaran yang dijanjikan pun tidak kunjung datang.

Tabel 3 Jumlah perolehan kursi/suara DPRD Sulawesi dapil Luwu Raya

\begin{tabular}{|l|c|c|c|}
\hline \multirow{3}{*}{ Partai politik } & \multicolumn{3}{|c|}{$\begin{array}{c}\text { Jumlah Perolehan } \\
\text { Luwu Raya }\end{array}$} \\
\cline { 2 - 4 } & $\mathbf{2 0 0 9}$ & $\mathbf{2 0 1 4}$ & $\mathbf{2 0 1 9}$ \\
\hline PKB & 0 & 1 Kursi & 36.827 (1 Kursi) \\
\hline Gerindra & 0 & 1 Kursi & 57.935 (1 Kursi) \\
\hline PDI Perjuangan & 24.265 (1 Kursi) & 1 Kursi & 53.216 (1 Kursi) \\
\hline Golkar & 81.575 (2 Kursi) & 2 Kursi & 86.276 (2 Kursi) \\
\hline Nasdem & 0 & 1 Kursi & 53.645 (1 Kursi) \\
\hline PDK & 22.812 (1 Kursi) & 0 & 0 \\
\hline PBB & 19.615 (1 Kursi) & 0 & 0 \\
\hline PKS & 32.800 (1 Kursi) & 1 Kursi & 62.166 (1 Kursi) \\
\hline PPP & 21.027 (1 Kursi) & 2 Kursi & 47.166 (1 Kursi) \\
\hline PAN & 63.916 (1 Kursi) & 0 & 66.128 (1 Kursi) \\
\hline Partai Hanura & 21.914 (1 Kursi) & 1 Kursi & 41.045 (1 Kursi) \\
\hline Partai Demokrat & 54.250 (2 Kursi) & 1 Kursi & 52.573 (1 Kursi) \\
\hline
\end{tabular}

Sumber: Diolah Penulis dari KPU Sulawesi Selatan (2019)

Pada Pilkada 2018 pertarungan duo Putra Daerah yang mempertemukan keluarga Kahar Mudzakkar. Sayangnya, suara pemilih untuk kedua putra Kahar dikalahkan oleh pasangan Nurdin Abdullan dan Andi Sudirman Sulaiman. Keberhasilan NA merebut suara di Tana Luwu karena hal yang dilakukan, sama seperti dengan yang dilakukan oleh SYL. Team pemenangan NA menggunakan isu pemekaran, sebagai pintu masuk untuk merebut perhatian masyarakat di kawasan Luwu Raya (BeritaNasional, 2019). Disaat yang sama, kegagalan SYL selama dua periode untuk mewujudkan pemekaran untuk Luwu berdampak pada perolehan suara Ikhsan YL yang cukup merosot. Masyarakat Luwu, memilih mengalihkan suaranya dari keluarga SYL karena alasan janji pemekaran yang tidak kunjung datang. Hal ini juga ditunjukan pada elit-elit lokal di Luwu. Sebelumnya berada pada garis depan mendukung keluarga SYL tetapi pada pilkada 2018 mengalihkan dukungannya pada pasangan NA.

Pemekaran Luwu Raya dalam pusaran elektoral sejauh ini memang cukup efektif untuk mendapat dukungan dari masyarakat Luwu. Masyarakat yang sudah lama menginginkan pemekaran tetapi tidak kunjung berlangsung, justru yang ada hanyalah janji-janji elektoral yang setiap lima tahun sekali di suarakan. Kendatipun demikian, harapan masyarakat Luwu akan adanya pemekaran masih sangat di nantikan, karena itu siapa pun yang menggunakan isu pemekaran Luwu akan mendapat dukungan besar baik oleh elit lokal maupun masyarakat pada akar rumput. Karena itu, pada konteks ini menurut hemat penulis pemekaran yang berlangsung pada Luwu raya sebagai arena konflik secara politik. Sebab, pemekaran akan menimbulkan konsekuensi yang besar. Salah satunya, pemekaran yang berlangsung pada Luwu Raya akan memecah kantong-kantong suara yang selama ini dipelihara oleh elit-elit di Provinsi induk (Elit Politik di Sulsel). Tana Luwu sebagai basis suara, menjadi keuntungan sendiri bagi elit politik di Sulsel, dengan kantong-kantong suara, elit politik dengan sangat mudah mengkonversi kantong- 
kantong suara tersebut menjadi dukungan elektoral, dengan sekali lagi melalui isu pemekaran Provinsi Luwu Raya.

Pemekaran pada konteks ini, secara tidak langsung akan memecah kantong-kantong suara. Jika berlangsung pemekaran, elit lokal di Sulsel tidak lagi punya jangkauan secara luas. Sebab, dengan adanya pemekaran di Luwu Raya, bersamaan dengan itu akan memunculkan elitelit baru (Agustino \& Yusoff, 2010; Burhan, 2020). Elit-elit baru inilah yang kemudian akan menjadi patron baru bagi masyarakat Luwu raya dan sekaligus menggantikan panggung bagi elit di ibukota Provinsi. Hal ini sangat terasa pada dukungan elektoral, bayangkan jika suara elektoral yang selama ini ada di Luwu raya hilang dalam elektoral. Hilang dalam artian disini, tidak lagi memberikan dampak elektoral. Sehingga sangat beralasan jika elit-elit khsususnya yang ada di Ibukota Provinsi merasa berat untuk melepaskan Luwu Raya dari Sulawesi selatan, sementara sebaliknya elit-elit dan putra Tana Luwu sangat gencar mendorong pemekaran. Sebab, ruang politik setelah pemekaran menjadi lebih terbuka dan berpeluang untuk dimanfaatkan. Pola ini oleh Selfina (2016) disebutnya sebagai Hidden Power, yaitu kepentingan terselubung dibalik narasi pemekaran. Pada konteks di Luwu Raya, bidden power sebagai isu yang hanya menyisir kelompokkelompok ditataran elit dan menjadi fenomena yang alamiah. Dari pengamatan penulis di lapangan, bidden power digulirkan khususnya bagi putra daerah yang selama ini tersisih dari panggung politik lokal.

Tana Luwu selama ini dikenal sebagai daerah yang banyak mecetak politisi-politisi unggul yang berkiprah di kancah nasional. Salah satunya Pak Lutfi. Pak Luthfi Andi Mutty sebagai putra daerah Luwu sekaligus sebagai orang yang sangat vokal untuk mendorong pemekaran Provinsi Luwu Raya. Sikap politik yang ditunjukan oleh Luthfi pun tidak terlepas dari susupan kepentingan yang secara pribadi sangat kental pada diri Luthfi. Selama ini pak Luthfi sebagai putra Luwu tidak pernah mendapat ruang di panggung politik lokal, beberapa kali dirinya diisukan akan maju sebagai Gubernur dan bahkan wakil gubernur dan selama itu pula kegagalan terus menghantam Pak Luthfi. Sama dengan elit politik yang lain, Pak Luthfi juga tampil melalui narasi pemekaran yang akan dilakukan di Luwu raya. Meskipun sempat mendapat dukungan dari masyarakat akar rumput, tetapi di tataran elit di Sulsel Luthfi sama sekali mendapat ruang yang sangat kecil (Burhan, 2020).

Oleh penulis apa yang berlangsung pada Luthfi dan putra daerah lainnya yang mendorong pemekaran di Luwu sebagai hidden power. Kekuatan politik yang mencoba menggalang akar rumput untuk terus mendesak pemekaran. Harapannya dengan adanya pemekaran elit-elit lokal yang tersisih mendapat panggung yang lebih besar. Karena itu, bagi elitelit dan putra daerah pemekaran menjadi sesuatu yang harus segera dilakukan. Selaras dengan apa yang dikatan oleh Suaib \& Zuada bahwa demokrasi di Indonesia pasca reformasi muncul dengan wajah yang lebih menakutkan. Melalui serangkaian peristiwa dan agenda politik lokal, para pembajak demokrasi muncul dengan wajah-wajah baru. Salah satunya melalui local strongmen dan bos lokal (Suaib \& Zuada, 2015). Wajah baru inilah yang pada akhirnya melakukan pembajakan terhadap arena politik lokal. Pada konteks pemekaran, para local strongmen dan roving bandits menjadikan isu pemekaran sebagai panggung bagi mereka memperkuat jejaring politik di tingkat lokal. Momentum ini seiring dengan menguatnya arus politik lokal yang terhembus bersamaan dengan runtuhnya rezim otoritarianisme Orde Baru. Kendati demikian, perubahan yang berlangsung pun mengalami kemandekan. Alih-alih menciptakan demokrasi yang lebih dewasa, 
license

melalui wujud barunya yaitu elit lokal atau local strongmen dan roving bandits kembali muncul lewat isu pemekaran.

\section{Kesimpulan}

Berdasarkan analisis, setidaknya terdapat dua garis politik menyertai isu pemekaran pada studi kasus Luwu raya. Secara politik, pihak lain melihat pemekaran pada Luwu raya dapat berdampak buruk pada perolehan elektoral. Setelah pemekaran, kantong-kantong suara yang selama ini berlangsung di Tana Luwu akan pecah pasca pemekaran. Hal ini karena, pemekaran akan memunculkan elit dan patron yang baru, sekaligus menggantikan garis politik dan patron elit lama yang selama ini ada di Ibukota Provinsi (Makassar). Kemudian pada sisi lainnya, pemekaran sebagai ruang akan munculnya elit dan putra daerah. Melalui pemekaran, putra daerah mendapat ruang yang lebih besar untuk terlibat pada proses-proses politik yang akan berlangsung. Pemekaran menjadi ruang untuk membangun konsolidasi politik yang lebih solid.

Transisi sentralisasi ke desentralisasi memberikan ruang politik yang lebih besar kepada daerah. Melalui berbagai reformasi perundang-undangan serta perubahan struktur sosial politik yang berlangsung di Indonesia. Pranata terpusat dibawah bayang-bayang sentralisasi tidak lagi menjadi politik yang dominan. Pemerintahan daerah dan elit lokal kini menjadi pemain baru yang memainkan peran yang cukup dominan di tengah praktek desentralisasi. Pemerintah daerah dan elit lokal yang dalam wujud praktis lebih sering tampil sebagai "penantang" desentralisasi itu sendiri. Berbagai kebijakan di daerah yang di banyak kasus justru semakin mengerdilkan desentralisasi. Wacana pemekaran yang berlangsung di Luwu sebagai salah satu fenomena lokal yang termasuk ke dalam kategori yang semakin alot di bawah bayang-bayang desentralisasi daerah. Meminjam apa yang telah di sebut oleh Hadiz, bahwa desentralisasi justru ikut memperkeruh suasana yang berlangsung di daerah, desentralisasi ikut serta mendistribusikan wajah dominan desentralisasi dalam wujud yang lain (Hadiz, 2004). Pemekaran yang secara normatif di maksudkan untuk mempermudah layanan sosial serta meningkatkan penyelenggaraan pemerintahan, harus kandas. Penyebabnya, desentralisasi membuat konflik antara elit lokal semakin kompleks (Beier \& Ferrazzi, 1998; Comola \& Mello, 2010; Hadiz, 2004). Terutama untuk konflik yang berlangsung dalam arena elektoral (Ito, 2006, 2011). Senada dengan apa yang dilihat oleh Saiman, bahwa berlangsung konflik ditingkat pemerintahan meskipun dengan konteks yang berbeda (Saiman, 2017). Di Luwu, pemekaran yang rumit terjadi karena apa yang saya sebut sebagai "lumbung elektoral" tidak ingin di lepas oleh elit tertentu. Sehingga kendati wacana pemekeran berlangsung cukup lama, sampai menjadi "jualan politik" saat musim elektoral namun pada realisasi Luwu sebagai lumbung elektoral tetap di pertahankan sebagai bagian dari Sulawesi Selatan.

Abstraksi dari kasus yang berlangsung di Luwu menjadi pelajaran yang penting dalam memahami dinamika politik dan pemerintahan daerah pada satu sisi dan pemekaran pada sisi yang lain. Tautan antara keduanya tidak bisa di lepas terpisah. Pandangan umum yang selalu melihat pelaksanaan otonomi dan pemerintahan daerah secara terpisah dari praktek pemekaran daerah perlu di diskusikan lebih jauh. Penelitian ini menemukan jika pemekaran bukan hanya persoalan "teknis" yang tautannya hanya sebatas persoalan normatif. Lebih dari itu, pemekaran daerah perlu di lihat sebagai lanskap yang lebih kompleks, bahwa pemekaran daerah punya tautan yang saling erat dengan dinamika politik lokal. Ini sekaligus memberikan gambaran, tentang 
studi-studi selanjutnya yang akan melihat isu pemekaran di Indonesia. Apalagi dengan situasi bahwa pasca reformasi gelombang pemekaran di daerah semakin tidak terbendung. Artikel ini menjadi pembuka pemantik untuk riset lebih mendalam terutama untuk aspek-aspek politik yang bergandengan dengan isu pemekaran.

\section{Referensi}

Agustino, L., \& Yusoff, M. A. (2010). Pilkada dan Pemekaran Daerah dalam Demokrasi Lokal di Indonesia: Local Strongmen dan Roving Bandits. Jebat: Malaysian Journal of History, Politics, \& Strategic Studies, 37, 86-104. Retrieved from http:/ / ejournals.ukm.my/jebat/article/view/42224/10969

Bappenas. (2008). Studi Evaluasi (Impact) Penataan Daerah Otonom Baru Tahun 2008. Retrieved from https://www.bappenas.go.id/files/8813/8785/4695/Kajian_Evaluasi_Penataan_D OB_Tahun_2008.pdf

Beier, C., \& Ferrazzi, G. (1998). Fiscal decentralization in Indonesia: A comment on smoke and lewis. World Development, 26(12), 2201-2211. https://doi.org/10.1016/S0305750X(98)00116-8

BeritaNasional. (2019, November 20). Mahasiswa Tagih Janji Nurdin Abdullah Terkait Pemekaran Wajo Utara - BeritaNasional.ID. Retrieved November 20, 2020, from BeritaNasional.Id website: https://beritanasional.id/mahasiswa-tagih-janji-nurdinabdullah-terkait-pemekaran-wajo-utara/

Burhan, R. (2020). Pemekaran Sebagai Arena Konflik Ekonomi : Studi Pemekaran Pada Luwu Raya Reksa Burhan. Government: Jurnal Ilmu Pemerintahan, 13(1), 24-33. Retrieved from file:///C:/Users/FISIP/Downloads/9613-Article Text-28411-1-1020200320.pdf

Carnegie, P. J. (2008). Democratization and Decentralization in Post-Soeharto Indonesia: Understanding Transition Dynamics. Pacific Affairs, 81(4), 515-525. https://doi.org/10.5509/2008814515

Chaeruddin. (2019a, July 3). Fraksi PDIP Ingatkan Basmin-Syukur Soal Pemekaran Luwu Tengah. Retrieved November 20, 2020, from Sindonews.com website: https://makassar.sindonews.com/berita/28014/4/fraksi-pdip-ingatkan-basminsyukur-soal-pemekaran-luwu-tengah

Chaeruddin. (2019b, July 20). Wagub Sulsel Singgung Soal Pemekaran Luwu Raya di HUT Palopo. Retrieved November 20, 2020, from Sindonews.com website: https://makassar.sindonews.com/berita/27946/4/wagub-sulsel-singgung-soalpemekaran-luwu-raya-di-hut-palopo

Chaeruddin. (2020, November 16). Wakil Ketua DPR Janji Perjuangkan Pemekaran Luwu Tengah. Retrieved November 20, 2020, from Sindonews.com website: https://makassar.sindonews.com/read/234456/713/wakil-ketua-dpr-janjiperjuangkan-pemekaran-luwu-tengah-1605535900

Comola, M., \& Mello, L. de. (2010). Fiscal Decentralization and Urbanization in Indonesia. In World Institute for Development Economics Research (UNU-WIDER) (No. 58). Retrieved from https://www.wider.unu.edu/sites/default/files/wp2010-58.pdf

Ferrazzi, G. (2000). Using the "F" Word: Federalism in Indonesia's Decentralization Discourse. 
Publius: The Journal of Federalism, 30(2), 63-85. https://doi.org/10.1093/oxfordjournals.pubjof.a030085

Hadiz, V. R. (2004). Indonesian Local Party politics: A Site of Resistance to Neoliberal Reform.
Critical
Asian
Studies,
$36(4)$,
615-636.

https://doi.org/10.1080/1467271042000273275

Ito, T. (2006). The Dynamics of Local Governance Reform in Decentralizing Indonesia:

Participatory Planning and Village Empowerment in Bandung, West Java. Asian and African Area Studies, 5(2), 137-183. Retrieved from https://core.ac.uk/reader/39212530

Ito, T. (2011). Historicizing the Power of Civil Society: A Perspective from Decentralization in Indonesia. Journal of Peasant Studies, 38(2), 413-433. https://doi.org/10.1080/03066150.2011.559015

Koran Tempo. (2013, January 9). Ilham Janjikan Program 9 Plus 1 di Toraja - Makassar koran.tempo.co. Retrieved November 20, 2020, from koran.tempo.co website: https://koran.tempo.co/read/makassar/297166/ilham-janjikan-program-9-plus-1di-toraja?

Lagaligopos. (2013, November 21). Mahasiswa Kembali Desak DPRD Dan Gubernur Percepat Pemekaran Luwu Tengah - Lagaligopos.com. Retrieved November 20, 2020, from lagaligopos.com website: https://lagaligopos.com/read/mahasiswa-kembali-desakdprd-dan-gubernur-percepat-pemekaran-luwu-tengah

Mawardi, C. (2018, March 20). Isu Pemekaran Luwu Raya Jelang Pilgub Sulsel, Ini Kata Pengurus KNPI Luwu Utara - Tribun Timur. Retrieved November 20, 2020, from TribunLutra.com website: https://makassar.tribunnews.com/2018/03/20/isupemekaran-luwu-raya-jelang-pilgub-sulsel-ini-kata-pengurus-knpi-luwu-utara

Miller, M. A., \& Bunnell, T. (2013). Problematizing the Interplay between Decentralized Governance and the Urban in Asia. Pacific Affairs, 86(4), 715-729. https://doi.org/10.5509/2013864715

Nur, I., Wekke, I. S., \& et.al. (2017). Religion, State and Society : Exploration of Southeast Asia.

Pama'tan, J. (2018, June 5). Eks Pengurus Golkar Sulsel Sindir NH Soal Luwu Raya | Djournalist Politik. Retrieved November 20, 2020, from Politik.djournalist.com website: http://politik.djournalist.com/2018/06/05/eks-pengurus-golkar-sulselsindir-nh-soal-luwu-raya/

Ratnawati, T. (2007). Beberapa Permasalahan Pemekaran Wilayah Era Reformasi dan Alternatif Solusi. In Makalah Seminar Nasional AIPI XXI (Vol. 21).

Saiman. (2017). Kepentingan Pemerintah Pusat Dalam Pembangunan Infrastruktur Perbatasan Kalimantan Indonesia-Malaysia Era Presiden Susilo Bambang Yudhoyono Tahun 2009-2014. Jurnal Sosial Politik, 3(1), 142. https://doi.org/10.22219/sospol.v3i1.4405

Sindonews. (2018, June 20). Pemekaran Luwu Raya Jadi Isu Sentral Kampanye Akbar NH-Aziz. Retrieved November 20, 2020, from Sindonews.com website: https://makassar.sindonews.com/berita/10167/4/pemekaran-luwu-raya-jadi-isusentral-kampanye-akbar-nh-aziz

Smoke, P., \& Lewis, B. D. (1996). Fiscal Decentralization in Indonesia: A New Approach to an Old Idea. World Development, 24(8), 1281-1299. https://doi.org/10.1016/0305- 
Copyright (C) 2020, Suhardiman Syamsu, Reksa Burhan, Ade Irma Surani Haliq

This is an open access article under the CC-BY-SA license
ISSN 2088-8090 (Print) ISSN 2597-6648 (Online)

Sospol: Jurnal Sosial Politik

Vol 6 No 2 (2020), pp.267-280

750X(96)00042-3

Suaib, E., \& Zuada, L. H. (2015). Fenomena 'Bosisme Lokal' Di Era Desentralisasi: Studi Hegemoni Politik Nur Alam Di Sulawesi Tenggara. Jurnal Penelitian Politik, 12(2), 5169. Retrieved from http://ejournal.lipi.go.id/index.php/jppol/article/view/541

Sutiyo, Maharjan, \& Keshav Lall. (2017). Decentralization and Rural Development in Indonesia. In Decentralization and Rural Development in Indonesia. https://doi.org/10.1007/978981-10-3208-0_1

Talitha, T., Firman, T., \& Hudalah, D. (2019). Welcoming Two Decades of Decentralization in Indonesia: A Regional Development Perspective. Territory, Politics, Governance, 8(5), 690-708. https://doi.org/10.1080/21622671.2019.1601595

Warren, C., \& Visser, L. (2016). The Local Turn: An Introductory Essay Revisiting Leadership, Elite Capture and Good Governance in Indonesian Conservation and Development Programs. Human Ecology, 44(3), 277-286. https://doi.org/10.1007/s10745-0169831-z

Yahmin, Z. (2018, March 27). Iming-iming Pemekaran Daerah jadi Janji Kampanye - RILIS.ID. Retrieved November 20, 2020, from Rilis.Id website: http://rilis.id/iming-imingpemekaran-daerah-jadi-janji-kampanye

Zainuddin, L. (2018a, July 27). Nurdin Abdullah Janjikan Luwu Raya Daerah Pembangunan Prioritas. Retrieved November 20, 2020, from Sindonews.com website: https://makassar.sindonews.com/berita/11683/1/nurdin-abdullah-janjikan-luwuraya-daerah-pembangunan-prioritas

Zainuddin, L. (2018b, October 19). Pemekaran Luwu Raya Jadi Jualan Calon Anggota DPD RI. Retrieved November 20, 2020, from Sindonews.com website: https://makassar.sindonews.com/berita/15548/1/pemekaran-luwu-raya-jadi-jualancalon-anggota-dpd-ri

\section{Wawancara}

Mutty, Andi Luhfi. (2018). Makassar, Pada 25 September 2018.

Akbar, Abdi. (2018) Makassar, Pada 8 Oktober 2018. 